\title{
Pemberdayaan Potensi Guru SMK Kota Tegal dalam Pembuatan Hand Sanitizer untuk Pandemi Covid-19
}

\author{
Heru Nurcahyo*1, Aldi Budi Riyanta², Joko Santoso ${ }^{3}$ \\ 1,2,3 DIII Farmasi Politeknik Harapan Bersama \\ *e-mail: herunurcahyo@gmail.com
}

\begin{abstract}
Increasing the strengthening of teacher competency through Community Service activities in the preparation of hand sanitizers in deciding the spread of the Covid-19 outbreak for teachers and laboratory assistants of Harapan Bersama Tegal City. The limitations of the teachers and laboratory assistants in making hand sanitizers quickly and productively became the main study material discussed. The solution offered is to provide mentoring and training to teachers and laboratory assistants for the manufacture of hand sanitizers such as liquid forms, gels and herbal extracts. The training aims to improve the competence of teachers and laboratory assistants in increasing understanding in making hand sanitizer dosage forms to take a role in deciding the spread of covid outbreaks. This training activity is carried out for 3 days with material, making sedans and evaluating preparations to produce good hand sanitizers. The results of this PKM (Community service) found an increase in science and competence in the manufacture of hand sanitizer formulations by $21 \%$.
\end{abstract}

Keyword: hand sanitizers, PKM, teachers, Covid-19

\begin{abstract}
Abstrak
Peningkatan penguatan kompetensi guru melalui kegiatan Pengabdian Kepada Masyarat dalam pembuatan sediaan hand sanitizer dalam memutus penyebaran wabah Covid 19 untuk guru dan laboran SMK harapan Bersama Kota Tegal. Keterbatasan guru-guru dan laboran dalam pembuatan hand sanitizer secara cepat dan produktif menjadi bahan kajian utama yang dibahas. Solusi yang ditawarkan adalah dengan memberikan pendampingan dan pelatihan kepada guru dan laboran untuk pembuatan hand sanitizer seperti bentuk cairan, gel dan kominasi ekstrak herbal. Pelatihan bertujuan untuk meningkatkan kompetensi guru dan laboran dalam meningkatkan pemahaman dalam pembuatan bentuk sediaan hand sanitizer untuk mengambil peran dalam memutus penyebaran wabah covid 19. Kegiatan pelatihan ini dilakukan selama 3 hari dengan materi, membuat sedian dan evaluasi sediaan untuk mengahasilkan hand sanitizer yang baik. Hasil dari PKM (Pengabdian Kepada Masyarakat) ini didapatkan adanya peningkatan keilmuan dan kompetensi tentang pembuatan formulasi hand sanitizer sebesar $21 \%$.
\end{abstract}

Kata kunci : hand sanitizer, PKM, Guru, Covid-19

\section{PENDAHULUAN}

Pada awal 2020, dunia dikejutkan dengan mewabahnya pneumonia baru yang bermula dari Wuhan, Provinsi Hubei yang kemudian menyebar dengan cepat ke lebih dari 190 negara dan teritori. Wabah ini diberi nama coronavirus disease 2019 (COVID-19) yang disebabkan oleh Severe Acute Respiratory Syndrome Coronavirus-2 (SARS-CoV-2). Penyebaran penyakit ini telah memberikan dampak luas secara sosial dan ekonomi. Masih banyak kontroversi seputar penyakit ini, termasuk dalam aspek penegakkan diagnosis, tata laksana, hingga pencegahan (Susilo Dkk, 2020). Hingga 16 Juni 2020 tercatat 8.107.425 kasus, terdapat 438.580 orang meninggal dunia da nada 4.187.422 orang telah sembuh (Azanella, 2020). Sedangkan di Indonesia sendiri, pandemi ini tercatat pada 2 Maret 2020 dan terus bertambah hingga kini dan tersebar hingga 34 provinsi (Sulastri dkk, 2020; Armiani dkk, 2020).

Kota Tegal tak luput juga menjadi salah satu kota yang terkena imbasnya hingga menerapkan lokal lockdown pada akhir Maret 2020 (Rachmawati, 2020). Kota Tegal terkenal dengan Jepangnya Indonesia, kota yang dinamis dan metropolis membuat masyarakat luas kagum dengan hasil karya produksi home industri yang banyak diciptakan oleh anak negeri ini tak luput dari pandemi global covid-19. Akhir Maret terkonfirmasi seorang warga terkena 
covid-19. Walikota Tegal Dedy Yon Supriyono, menerapkan PSBB untuk menekan penyebaran covid-19 dan upaya tersebut membuahkan hasil hingga pada 20 Mei 2020 Kota Tegal dinyatakan sebagai zona hijau (Iqbal, 2020).

Saat ini, penyebaran SARS-CoV-2 dari manusia ke manusia menjadi sumber transmisi utama sehingga penyebaran menjadi lebih agresif. Transmisi SARS-CoV-2 dari pasien simptomatik terjadi melalui droplet yang keluar saat batuk atau bersin (Han dan Yang, 2020). Berbagai upaya masyarakat bahu-membahu memberikan pengetahuan tentang bahaya Covid19 seperti dengan penyuluhan tentang sosial distancing dan physical distancing, mencuci tangan dengan sabun secara rutin memakai hand sanitizer (Purnamasari, 2020; Riyanta dkk, 2020; Liputan 6, 2020).

Kegiatan Pengabdian kepada Masyarakat ini merupakan Program Pengabdian kepada Masyarakat yang diselenggarakan Pusat Penelitian dan Pengabdian Masyarakat Politeknik Harapan Bersama tahun anggaran 2020 dimana pelaksanaannya di fokuskan pada peningkatan pencegahan wabah covid 19 khususnya di Kota tegal. Program kemitraan ini dengan SMK Harapan Bersama, dimana berdasarkan surat yang masuk bahwasanya permohonan sekolah tersebut untuk dapat diberikan pembelajaran dan pelatihan pembuatan hans sanitizer untuk guru dan laboran yang hasilnya nantinya akan dibagikan secara gratis untuk masyarakat. Pendalalam yang dilakukan terhadap guru dan laboran SMK tersebut ternyata yang memiliki prodi farmasi dan kesehatan hanya terfokus pada pembelajaran pelayanan sehingga kurang kompeten dalam pembuatan produk.

Lemahnya kompetensi guru dan laboran dalam pembuatan produk menjadikan fokus kegiatan dalam pemantaban dalam pemberian materi dan pelatihan pembuatan produk, kegiatan tersebut diperuntukkan untuk guru dan laboran diharapkan agar nantinya setelah mengikuti kegiatan tersebut dapat melaanjukan kegiatan sendiri di SMK dan ditransferkan pengetahuannya kepada siswa didiknya agar mampu membuat produk hand sanitizer secara mandiri. Solusi yang ditawarkan untuk meningkatkan kompetensi guru dan laboran yaitu dengan pendalaman materi tentang bentuk-bentuk sediaan, formulasi, cara pembuatan, cara pengujian sediaan dan evaluasinya sehingga produk tersebut layak untuk digunakan oleh masyarakat. Kegiatan tersebut dilaksanakan selama 3 hari dengan fokus materi yang berbeda, pada hari pertama difokuskan pada pemahaman dan pada hari ke 2 difokuskan pada pembuatan sediaan dan hari ketiga difokuskan pada evaluasi sediaan hand sanitizer.

\section{METODE}

Kegiatan ini terlaksana melalui beberapa tahapan metode atau langkah-langkah dalam melaksanakan solusi yang ditawarkan untuk mengatasi permasalahan tersebut. Berdasarkan permasalahan yang dihadapi sekolah maka salah satu solusi yang dapat dilakukan adalah membekali pengetahuan tentang pembuatan sediaan hand sanitizer, memberikan pelatihan pembuatan hand sanitizer dan memberikan pelatihan evaluasi sediaan hand sanitizer.

Kelengkapan dalam kegiatan ini seperti: mempersiapkan tempat pelaksanaan pelatihan, yaitu dengan mempersiapkan Laboratorium, laboratorium yang digunakan adalah laboratorium teknologi farmasi milik prodi Farmasi politeknik harapan Bersama. Pembuatan modul yang digunakan dalam pelatihan. Modul yang dimaksud dibuat oleh panitia pelaksana (trainer) dengan cakupan berupa materi-materi yang diberikan dalam pelatihan. Modulnya dibuat dalam bentuk tutorial dan teori dengan maksud untuk memudahkan peserta dalam pemahaman materi.

Mempersiapkan media presentasi interaktif yaitu slide presentasi yang dibuat oleh trainer termasuk infocus/ LCD Proyektor dan materi pendukung lainnya yang akan dibutuhkan oleh peserta, seperti training kit (nametag, daftar hadir, dan sertifikat), memastikan kelengkapan konsumsi, dan berkas pendukung lainnya. Mempersiapkan alat dan bahan yang digunakan dalam pelatihan, yaitu bahan formulasi, alat glas, dan alat uji sediaan hand sanitizer. 
Metode Pendekatan yang ditawarkan untuk menyelesaikan persoalan yang telah disepakati bersama adalah mengadakan presentasi materi, diskusi, dan tanya jawab. Dalam sesi materi ini, peserta didata ulang berdasarkan informasi yang diperoleh pada saat pendaftaran. Sebelum materi dimulai, masing-masing peserta diberi alat tulis serta modul pelatihan. Dalam kegiatan ini guru dan laboran diberikan pretes aal untuk mengetahui tingkat pemahaman tentang sediaan hsnd sanitizer, selanjutnya diberikan materi pendalam tentang sediaan tersebut dan di akhir sesi tahap pertama diberikan postest tentang materi yang diberikan untuk mengukur tingkat pencapaian pemahaman yang diberikan dalam pelatihan ini.

Aplikasi dari hasil materi pada hari sebelumnya dengan pelatihan (workshop) untuk mengimplementasikan dari pemahaman tentang pembuatan sediaan hand sanitizer. Pada kegiatan ini tim pelaksana memberikan kontribusi dalam bentuk:

1. Mengkoordinir guru dan laboran yang akan dilatih,

2. Menjelaskan k3 laboratorium kepada seluruh peserta

3. Mempersiapkan tempat untuk workshop yaitu laboratorium

4. Mempersiapkan dan memfasilitasi sarana prasarana yang dibutuhkan seperti bahan dan alat untuk praktek

Pada kegiatan pelatihan ini, tim memberikan pendampingan dalam membuat sediaan sambil mengulang informasi meteri atau tahapan-tahapan dalam pembuatan sediaan yang sudah diberikan hari sebelumnya, kegiatan pelatihan ini memiliki target setiap peserta guru dan laboran memiliki kemampuan yang sama untuk membuat sdiaan denagn baik sesui prosedur pada materi yang sudah diberikan.

\section{HASIL DAN PEMBAHASAN}

Kegiatan pengabdian ini terlaksana antara Prodi D3 Farmasi PHB yang beralamat di Jl. Mataram No 9 Kota tegal dengan SMK Harapan Bersama Kota Tegal yang beralamat di Jl Abdul Syukur Kec. Margadana, dimana kegiatan ini diawali dengan adanya surat permintaan dari sekolah untuk memberikan worshop pembuatan sediaan hand sanitizer, selanjutnya diadakan kegiatan survai kesekolah untuk mengetahui data perserta, kebutuhan pelatihan, tempat pelatihan dan jawaban dari surat yang merupakan tindak lanjut dari kegiatan tersebut. Pelaksanaan kegiatan ini selama 3 hari yang bertempat di Laboratorium Teknologi Farmasi Prodi D3 Farmasi PHB dengan rincian kegiatan sebagai berikut:

Hari pertama, dilaksanakan pada tanggal 19 maret 2020, jam 9 sd jam 12 wib, diawali dengan mengecek ulang data peserta, absensi, pretest dan dilanjutkan materi, setelah diberikan pendalaman tentang materi pembuatan sediaan hand sanitizer, peserta juga dijelaskan karakteristik bahan yang akan digunakan dalam pembuatan sediaan. Kegiatan pada hari pertama diakhiri dengan posttest pada penghujung kegiatan.

Mengawali kegiatan pada hari pertama dengan pre test, yang bertujuan untuk mengukur kemampuan peserta, khususnya yang berkaitan dengan soal-soal mendasar tentang sediaan hand sanitizer, karakteristik bahan, cara pembuatan dan evaluasi sediaan. Hasil dari pre test dijadikan sebagai pembanding tingkat keberhasilan tim dalam memberi workhop kepada peserta. Selain itu, hasil tersebut juga digunakan untuk melihat peningkatan pemahaman materi guru dan laboran yang diberikan untuk memahami peningkatan pemahaman pasca pemberian materi serta untuk memudahkan dalam menyiapkan kegiatan pada hari kedua. 


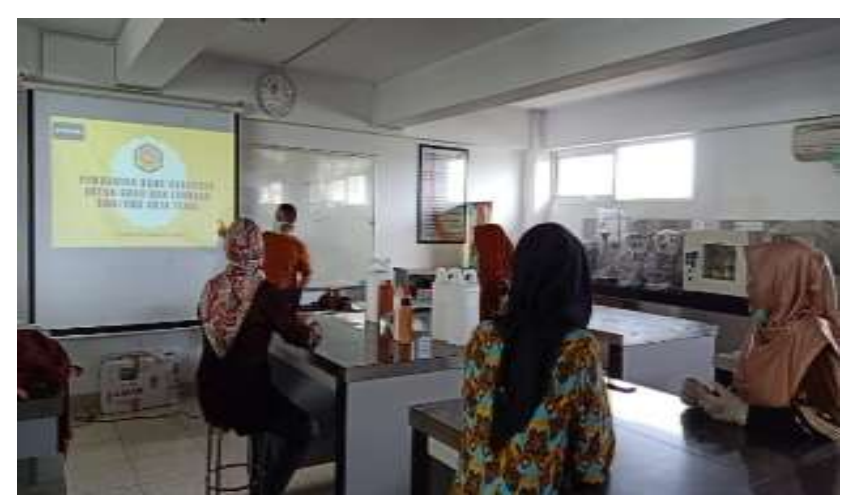

Gambar 1. Pelaksanaan pendalaman materi

Pemberian materi diberikan secara mendalam kepada peserta untuk menngkatkan kompetensinya seperti pada pembuatan formulasi, dimana dikenalkan tentang karakteristik bahan, karakteristik bentuk sediaan seperti cairan dan gel, membaca literasi hand book untuk penentuan standar formula serta pengujiaan sediaan sehingga hasilnya nanti dapat dipertanggungjawabkan dan siap dibagikan kepada masyarakat. Dalam kegiatan tersebut mitra juga diberikan edukasi tentang covid-19 sehingga diharapkan ada upgrade pengetahuan dalam rangka turut serta untuk memutus mata rantai penyebaran wabah tersebut.

Setelah kegiatan materi diakhir sesi dilakukan post test, dijadikan sebagai evaluasi oleh tim pelaksana, yaitu dengan membandingkan hasil post test dengan pre test untuk mengetahui nilai peningkatan pemahamannya serta kepuasan kegiatan (Nurcahyo dkk, 2015). Hasil peningkatan nilai pemahaman dapat dilihat pada Gambar 2. dibawah ini:

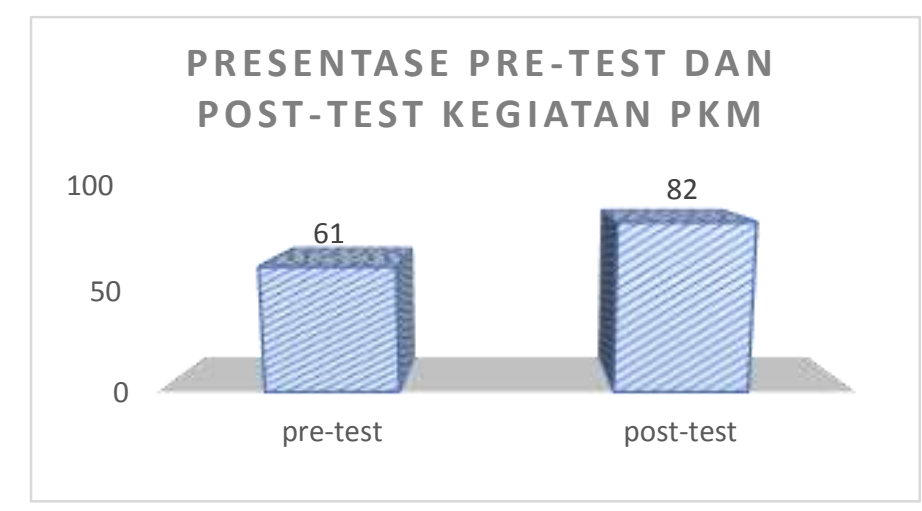

Gambar 2. Prosentase Hasil Pre test dan Post test Kegiatan PKM

Hasil kegiatan pretes mendapatkan nilai rata-rata 61 dan hasil posttest mendapatkan nilai rata-rata 82 , terjadi peningkatan pemahaman sejumlah $21 \%$ sebagai persiapan untuk melahkan pada kegiatan workshop dihari selanjutnya.

Hari kedua, dilaksanaan pada tanggal 20 maret 2020, jam 9 sd jam 14 wib, dengan agenda worksop pembuatan sediaan, peseerta diberikan kesempatan untuk membuat formula sendiri untuk meningkatkan khasanah keilmuan tentang sediaan hand sanitizer. Kegiatan workshop dilaksanakan di laboratorium farmasi dengan agenda membuat sediaan dari formulasi yang sudah ada dan peserta diperbolehkan untuk memodifikasi formula sesui bahan yang tersedia di laboratorium. Kegiatan tersebut dimualai dengan memahami alat-alat yang akan digunakan, karakteristik bahan, menimbang sesuai formula, mencampur bahan dan menempatkan wadah hasil sediaan. 


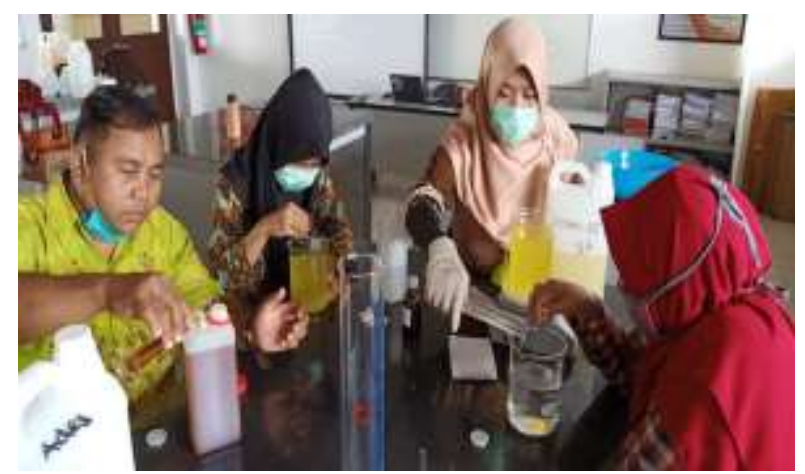

Gambar 3. Pembuatan Sediaan Hand Sanitizer

Hari ketiga, dilaksanaan pada tanggal 21 maret 2020, jam 9 sd jam 15 wib, dengan agenda evaluasi sediaan hand sanitizer yang telah dibuat sebelumnya, serta peserta diberikan kesempatan untuk membuat sebanyak 20 liter dan mitra membuat 60 liter untuk dapat dibagikan kepada masyarakat.

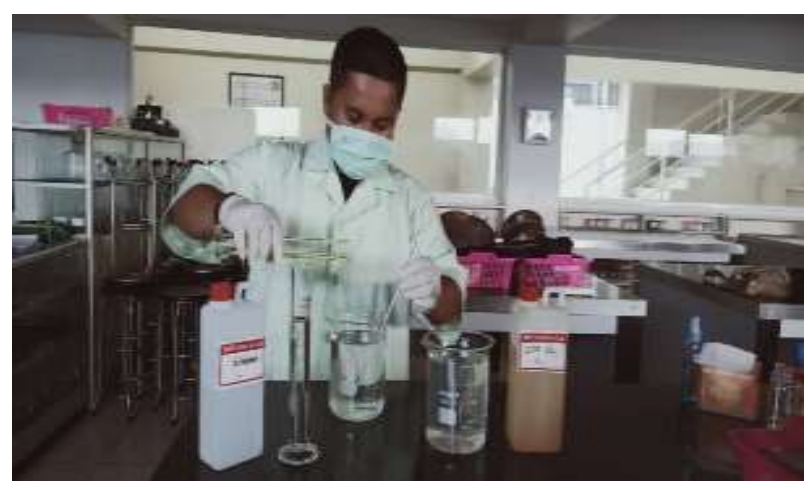

Gambar 4. Evaluasi Sediaan Hand Sanitizer

Kegiatan hasil formulasi yang sudah dienapkan selama kurang lebih 24 jam selanjutkan akan dievaluasi sediaan seperti organoleptis (bentuk, bau dan warna), homogenitas, pH sediaan (Nurcahyo dan Sari, 2019) untuk mengetahui tingkat asam basa sediaan, dan uji coba sediaan dengan diguankan secara langsung dengan tujuan untuk mengetahui kenyamanan seperti tingkat lengket, rasa panas ditangan serta iritasi sediaan. Hasil pengujian yang terbaik selanjutnya dibuat sediaan dalam jumlah besar dan dikemas dalam botol ukuran $30 \mathrm{ml}$ yang siap untuk dibagikan kepada masyarat secara gratis.

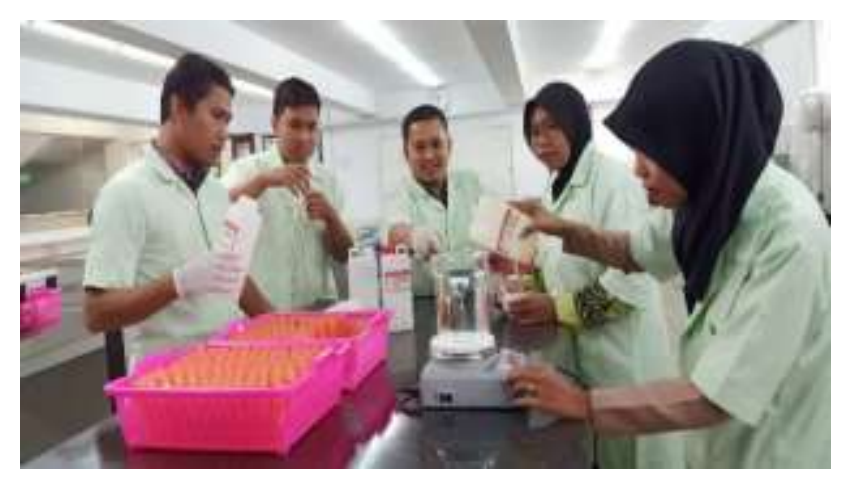

Gambar 5. Pengemasan Hand Sanitizer 
Kegiatan penutupan PKM diisi dengan diskusi untuk peningkatan perbaikan kegiatan berikutnya. Tim juga memberikan memotivasi kepada para peserta pelatihan agar terus belajar dan meningkatkan kompetensi baik secara individu maupun kelompok. Hal itu dilakukan dengan harapan agar pihak sekolah, khususnya guru dan laboran dapat memanfaatkan modul pelatihan tersebut dalam proses peningkatan skil pembuatan sediaan hand sanitizer untuk siswa SMK.

\section{KESIMPULAN}

Simpulan

Peningkatan SDM sangat penting untuk terus ditingkatkan terytama kemampuan guru dan laboran perlu ditingkatkan agar terjadi peningkatan pengetahuan dan skil bagi siswanya, workshop merupakan salah satu solusi untuk meningkatkan dan mendalami materi tersebut kususnya pada pembuatan sediaan hand sanitizer, dari hasil evaluasi pre test dan post test didapatkan peningkatan nilai sebesar $21 \%$, harapannya dapat digunakan kembali untuk meningkatkan kompetensi sekolah.

Saran

Melihat dari hasil evaluasi dan analisis ini, perlu diadakan keiatan worksop yang berkelanjutan dengan tema-tema baru untuk meningkatkan kompetensi guru, laboran sehingga peningkatan kemampuan tersebut dapat diterapkan untuk peningkatan kompetesni siswa SMK.

\section{UCAPAN TERIMA KASIH}

Ucapan terima kasih terutama ditujukan kepada unit P3M Politeknik Harapan Bersama atas dana yang diberikan untuk tercapainya kegiatan pengabdian kepada masyarakat ini dan Kepala SMK Harapan Bersama atas program kemitraan ini semoga bisa bermanfaat untuk meningkatkan kompetensi.

\section{DAFTAR PUSTAKA}

Susilo, A dkk, 2020, Coronavirus Disease 2019: Review of Current Literatures, Jurnal penyakit dalam indonesia, Vol.7 No 1Universitas Indonesia, Diakses 16 Juni 2020

Sulastri, N. M., Maharani, J. F., \& Sarilah. (2020). Mendongeng Bersama Anak sebagai Upaya Pencegahan Covid 19. Jurnal Pengabdian UNDIKMA: Jurnal Hasil Pengabdian \& Pemberdayaan kepada Masyarakat, 34-38

Azanella, L. A. (2020). Update Virus Corona 16 Juni: 8,1 Juta Orang Terinfeksi / 4,1 Juta Orang Sembuh. Jakarta: Kompas.com.

Armiani, S., Fajri, R. S., Sukri, A., Pidiawati, B. Y. (2020). Pelatihan Pembuatan Masker Sebagai Upaya Antisipasi Penyebaran Covid-19 di Desa Anyar Kabupaten Lombok Utara. Jurnal Pengabdian UNDIKMA : Jurnal Hasil Pengabdian \& Pemberdayaan kepada Masyarakat, 22-27.

Han Y, Yang H. The transmission and diagnosis of 2019 novel coronavirus infection disease (COVID-19): A Chinese perspective. J Med Virol. 2020; published online March 6. DOI: 10.1002 / jmv.25749

Nurcahyo, H., Marchaban, Sumarni, 2015, The Relation Of Outpatient Service Quality On The Era Of The National Health Insurance Towards Patient Satisfaction, Jurnal Manajemen dan Pelayanan Farmasi, Volume 5 Nomor 2, h 104-108.

Nurcahyo, H., Sari, M.P., 2019, Pengaruh Mordanting Dan Pemanasan Pada Pewarnaan Kain Dari Pewarna Alami Antosianin Ekstrak Bunga Rosella (Hibiscus sabdariffa L.), Jurnal Farmasi Galenika Vol. 6 No.3, h.142-151

Iqbal, M. (2020). Barvo! PSBB Berakhir Hari Ini, Kota Tegal Nol Kasus Covid-19. Jakarta: CNBC Indonesia.

Liputan 6. 3 April 2020. Cegah Virus Corona Covid-19, Simak Cara Membuat Hand Sanitizer Berdasar Anjuran WHO. Jakarta: Liputan 6.Com. 
Purnamasari, D. M. (2020). Imbauan Pemerintah Atasi Covid-19 : Physical Distancing Hingga Tak Mudik. Jakarta: Kompas.

Rachmawati. (2020). Kota Tegal: "Lock Down" Saat Zona Merah dan Pesta Kembang Api Usai $P S B B$. Jakarta: Kompas.

Riyanta, A. B., Putri, A. R., \& Susanto, A. (2020). Pemanfaatan Footsanitizer Spray Dapat Menumbuhkan Jiwa Wirausaha Bagi Siswa SMK Bisma Di Kersana Kabupaten Brebes. Jurnal Abdimas PHB Vol 3 No 1 Januari Tahun 2020 , 27-31. 